\title{
Comments to the letter to the Editor on the paper "Exposure to organic solvents and cytogenetic damage in exfoliated cells of the buccal mucosa from shoe workers" by González-Yebra et al. (2008)
}

\author{
Carlos Kornhauser • Ana-Lilia González-Yebra • \\ Gloria Barbosa-Sabanero
}

Received: 3 November 2008 / Accepted: 5 November 2008 / Published online: 26 November 2008

(C) Springer-Verlag 2008

Dear Sir,

Regarding the letter concerning our article, GonzálezYebra et al. (2008), we want to make some statements.

First: We reported median instead of means because our data did not show a normal distribution.

We acknowledge the accidental typing error made in the text of the discussion where we wrote a median of 0 , the correct value is 0.1 as shown in Table 3 .

As for the alcohol consumption and its possible relationship with the induction of micronuclei, we carried out two types of analysis as described in the materials and methods. The Kruskal-Wallis test to identify differences between the study groups. With this analysis we found a significant difference between the alcohol consuming exposed group and the non alcohol consuming exposed group. Afterwards we conducted a multiple regression analysis to identify the variables associated with the presence of micronuclei, with this analysis we found no association with the consumption of alcohol. It is possible that the Kruskall-Wallis analysis shows a synergism between exposure to solvents and alcohol consumption.

We agree with the author of the letter on the irrelevance of the reference Fenech et al. (1985).

As for the commentary on the evaluation of only 1,000 exfoliated cells, we would like to emphasize that we scored at least one thousand cells (Material and methods right column last paragraph), according to Tolbert et al. (1992), Gonsebatt et al. (1997), Reis et al. (2002), Domínguez et al. (2005) and we can provide another reference, Wu et al. (2004).

C. Kornhauser $(\square)$ · A.-L. González-Yebra .

G. Barbosa-Sabanero

University of Guanajuato, Leon, Guanajuato, Mexico

e-mail: carloskornhauser@yahoo.com.mx
We thank the advice on the evaluation of cells by means of oil immersion and magnification $\times 1,000$ and may consider it for future studies.

With are positive that Fig $1 \mathrm{~b}$, is a broken egg phenomenon, clearly showing a smaller fragment irregularly shaped.

We apologize for the very few lapses in which we have incurred in our English writing on our paper, and most of all for not having erased the Spanish "nucleos rotos" for broken eggs.

\section{References}

Domínguez O, Rojas V, Romero G, Rodríguez T, Pérez A (2005) Lesiones citológicas bucoepiteliales en trabajadores expuestos a productos químicos. Rev Med IMSS 43(3):221-227

Gonsebatt ME, Vega L, Salazar AM, Montero R, Gusman P, Blas J, Del Razo LM, García-Vargas G, Albores A, Cebrián ME, Kelch M, Ostrosky-Wegman P (1997) Cytogenetic effects in human exposure to arsenic. Mutant Res 392(1-2):11-18

González-Yebra AL, Kornhauser C, Barbosa-Sabanero G, Pérez-Luque EL, Wrobel K, Wrobel K (2008) Exposure to organic solvents and cytogenetic damage in exfoliated cells of the buccal mucosa from shoe workers. Int Arch Occup Environ Health. 3 July, [Epub ahead of print]

Reis SR, Sadigursky M, Andrade MG, Soares LP, Espirito Santo AR, Vilas Boas DS (2002) Genotoxic effect of ethanol on oral mucosa cell. Pesqui Odontol Bras 16:221-225

Tolbert PE, Shy CM, Allen JW (1992) Micronuclei and other nuclear anomalies in buccal smears: methods development. Mutat Res 271:69-77

Wu PA, Loh CH, Hsieh LL, Liu TY, Chen CJ, Liou SH (2004) Clastogenic effect for cigarette smoking but not areca quid chewing as measured by micronuclei in exfoliated buccal mucosal cells. Mutat Res 562(1-2):27-38 